\title{
THE ROLE OF THE CONTRARIUS ACTUS PRINCIPLE IN OVERSIGHT OF THE GROWTH AND DEVELOPMENT OF COMMUNITY ORGANIZATIONS
}

\author{
Muhammad Yasin Izhharulhaq ${ }^{1}$, Adrian E. Rompis ${ }^{2}$, Amelia Cahyadini ${ }^{3}$ \\ 1,2,3 Faculty of Law, Universitas Padjadjaran \\ Email: yasinizhhar@gmail.com, amelia.cahyadini@unpad.ac.id
}

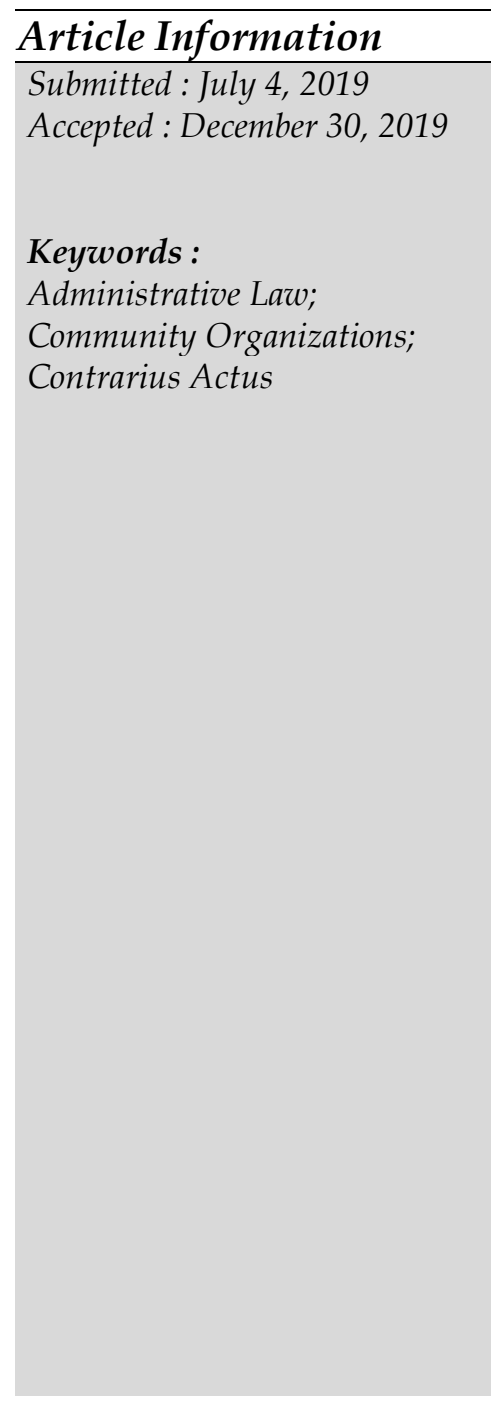

\begin{abstract}
The term contrarius actus principle is deemed not to exist in Law Number 17 of 2013 on Community Organizations (hereinafter to as CSOs) so that it explicitly states that the Perppu of CSOs contains the principle of contrarius actus in its application. The existence of this principle as referred to in the consideration of the Public Order Perppu lies in the process of applying sanctions where the process is part of the follow-up process of supervisory actions carried out by government officials. Thus, that role in terms of supervision should be studied more deeply in connection with the growth and development of community organizations at this time. The research method with a normative juridical approach, prioritizes library research and its implementation in practice. Research specifications are descriptive. The research phase is carried out through library research, collecting secondary data in the form of primary, secondary, and field research materials to obtain primary data as support. Based on the analysis conducted by the author regarding the role of the principle of contrarius actus in monitoring the growth and development of community organizations, the author raises the role of the principle of contrarius actus in terms of supervision of CSOs as the application of sanctions in the form of administrative sanctions, which are emphasized by the role of responding or reacting to non-compliance with provisions the provisions contained in the decision which in this case are ratification as registered $C B O s$ and also ratification of CSOs as legal entities, in other words that the placement of sanctions in the case of mass organization supervision is a follow-up to the results of monitoring and evaluation by external supervisors with the aim that can control the initial purpose of the establishment of a mass organization that is in accordance with the objectives of the state and national development.
\end{abstract}

\section{INTRODUCTION}

Society in the democratic order in its development consciously creates symptoms of organizational activities that occur naturally because essentially each individual has a tendency to live in groups and be organized. The demand in social life is the natural tendency of every individual human being as a social creature, so the tendency to group and organize is also a natural tendency found in every society. Its inherent nature can be said as a form of natural rights so that it needs to be regulated in the constitution. The provisions concerning this matter are found in Article 28 of the 1945 Constitution of the Republic of Indonesia (1945 Constitution) which states that: "Freedom of 
association, assembly and expression of thoughts verbally and in writing and so on shall be determined by law" which then occurs the second amendment is regulated in Article 28E of the 1945 Constitution, which states: "Everyone has the right to freedom of association, assembly and expression."

Starting with Law No. 8 of 1985 concerning Community Organizations, it made a fresh breeze for the community because by the existence of regulations regarding community organizations, they provided more guarantees of freedom of association or organization, also through this law, gave an understanding that the position of a Community Organization ( CSOs) in a democratic country become very necessary because it serves as a forum for the community to channel opinions and thoughts. UU no. 8 of 1985 provides the understanding that Community Organizations are organizations formed by members of the community voluntarily on the basis of shared activities, professions, functions, religions, and belief in God Almighty. This understanding also explains that CSOs have the role of their members in the framework of development to achieve national goals. The issuance of this Law is mandated by Chapter IV of the MPR TAP. No. II / MPR / 1983 which states;

In order to increase the role of social organizations in National Development in accordance with their respective fields of professional and functional activities, it is necessary to increase efforts to strengthen and organize these organizations. For this reason, it is necessary to draft a law on social organization.

Thus the initial intention in guaranteeing freedom of association and assembly has more value as a means of strengthening national unity and unity as well as encouraging community participation in development that relies on the Unitary State of the Republic of Indonesia. The state's efforts to develop this matter did not stop there then in 2013 because it was considered the Social Organization from year to year to experience growth as well as development, then was issued Law Number 17 of 2013 concerning Community Organizations that replaced Law Number 8 of 1985. Changes That makes the definition of mass organizations very broad scope mentioned that in Article 1 paragraph (1) of Law no. 17 of 2013, "Social Organization is an organization that was founded and formed by the community voluntarily based on shared aspirations, desires, needs, interests, activities and objectives to participate in development for the achievement of the objectives of the Unitary State of the Republic of Indonesia based on Pancasila". As a result, all types of organizational forms can be included in the understanding of CSOs and directly impact the growth in the number of CSOs in Indonesia, such phenomena have two angles where one side states that the rights and freedoms of people in association or organization have been fulfilled but in the other side of the protection of security and public order must also be an agenda whose implementation is overseen by the government as the organizer of the state, which lately is not without cause. Organizations that have been formed to date with the number reaching tens of thousands or even hundreds of thousands certainly have different ways in carrying out the activities or activities organized by these CSOs which are not uncommon in their implementation to encounter problems that disturb the public interest in social life as well as the state. In response to this, supervision is needed both in the form of rules and practical levels in monitoring the growth and development of Community Organizations in Indonesia. One of the efforts that have been made is the inclusion of rules regarding supervision in the special Chapter on supervision in Articles 53 - 56 of Law no. 17 of 2013. Article 53 of Law No. 17 of 2013 states that: 
1. To improve the performance and accountability of Community Organizations or Community Organizations established by foreign citizens as referred to in Article 43 paragraph (2), internal and external supervision is conducted;;

2. Internal supervision of Community Organizations or Community Organizations established by foreign nationals as referred to in paragraph (1) shall be carried out in accordance with the organizational mechanisms stipulated in the Statutes/ ByLaws;

3. External supervision as referred to in paragraph (1) shall be carried out by the community, the Government, and / or the Regional Government.

Furthermore Article 54 states that:

1. To guarantee the implementation of the functions and objectives of Community Organizations, every Community Organizations or Community Organizations established by a foreign citizen as referred to in Article 43 paragraph (2) has an internal supervisor;

2. Internal supervisors as referred to in paragraph (1) function to enforce the organization's code of ethics and decide on sanctions within the organization's internal;

3. The duties and authority of the internal supervisor as referred to in paragraph (1) shall be regulated in the Statutes and By-Laws or by organizational regulations.

The forms of supervision are regulated in Article 55 which states that:

1. The form of supervision by the community as referred to in Article 53 paragraph (3) may be in the form of complaints;

2. Complaints as referred to in paragraph (1) shall be submitted to the Government or Regional Government.

Picture 1. Flowchart of Oversight in Law No. 17 of 2013 concerning Community Organizations
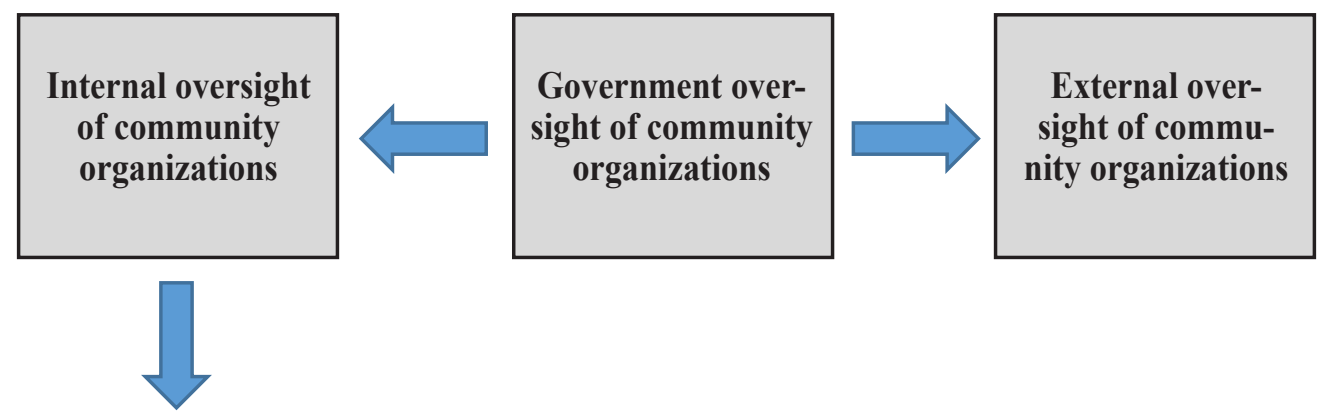

1. Statutes/ByLaws community organizations

2. Code of ethics

3. Sanctions

The supervision carried out has an important function to achieve the state objectives that have been determined in Paragraph 4 of the Preamble to the 1945 Constitution, including Protecting the whole nation and the whole of Indonesia's bloodbath; Promote general welfare; Enrich the life of a nation; and Join in carrying out world order based on 
independence, eternal peace and social justice. Moreover, it is added that the presence of CSO arrangements is as a forum for the community to be able to participate in national development so that if an CSO is formed and implemented not in accordance with these objectives, it is necessary to take further action from the supervision conducted by the government to be corrective to CSOs that are not in accordance with the objectives as already mentioned at the beginning of the paragraph. The follow up actions can take various forms including reprimand, freezing, and dissolution. The action was taken not without cause as by definition it can be interpreted that the action was aimed at CSOs which were indicated to be incompatible with national goals and development as well as specifically stipulated in Article 59 of Law No. 17 of 2013 concerning Community Organizations states that:

1) Community Organizations are prohibited:

a. use the same flag or symbol as the flag or coat of arms of the Republic of Indonesia to become a mass organization flag or symbol;;

b. use the same name, symbol, flag, or attribute as the name, symbol, flag, or attribute of a government institution;

c. using without permission the name, symbol, flag of another country or international institution / body into the name, symbol, or flag of the Community Organizations;

d. use the names, symbols, flags or symbols of organizations that have similarities in principle or in whole with the names, symbols, flags or symbols of separatist movements or banned organizations; or

e. use names, symbols, flags or image marks that have similarities in principle or in whole with names, symbols, flags, or other party organizations or political parties.

2) Community Organizations are prohibited:

a. conduct acts of hostility towards ethnicity, religion, race, or class;

b. committing abuse, blasphemy, or blasphemy against religions practiced in Indonesia;

c. conduct separatist activities that threaten the sovereignty of the Unitary State of the Republic of Indonesia;

d. commit acts of violence, disturb public order and order, or damage public facilities and social facilities; or

e. carry out activities that are the duty and authority of law enforcement in accordance with statutory provisions.

3) Community Organizations are prohibited:

a. receive from or give to any party any contribution that is contrary to the provisions of the legislation; or;

b. raising funds for political parties.

c. Community Organizations are prohibited from adhering to, developing, and spreading teachings or understandings that are contrary to Pancasila.

This regulation is a form of limitation of the community in using its right to organize which characterizes the journey of a democratic country which, if found violations committed by a mass organization, will be subject to sanctions. The spectrum is a continuous series of Oversight by Government Officials or commonly referred to as 
Officials of State Administration of Community Organizations in Indonesia. However, in the level of implementation in the process of continued supervision in terms of imposing sanctions according to Law No. 17 of 2013 concerning Community Organizations is considered too complicated and complicated, it is briefly seen that the rules mentioning CSOs that are indicated to have committed violations must be reprimanded in the form of written warnings three times then if it still violates, it will freeze further activities if it still violates the new organization. dissolution. The liquidation must go through a fatwa issued by the Supreme Court. The lengthy process of the process makes it difficult for State Administration Officials as licensors and supervisors to take action because it seems that violations committed by CSOs can automatically be 'forgiven' and their role becomes slow and allows them to act against CSOs that are indicated to violate the provisions.

The government certainly reads the situation especially considering that every legal regulation is the government's guideline in organizing a country. In 2017 the Government issued Government Regulation in Lieu of Law Number 2 of 2017 concerning Amendments to Law Number 17 of 2013 concerning Community Organizations (Perppu Ormas). The considerations contained in the Perppu on Civil Society Organizations explained legally the two reasons for the issuance of the Perppu on Community Organizations. First, that Law Number 17 of 2013 concerning Social Organizations urges immediate changes to be made because it has not comprehensively regulated Community Organizations that are in conflict with Pancasiala and the 1945 Constitution of the Republic of Indonesia so that there is a legal vacuum in the application of effective sanctions. Secondly, that Law No. 17 of 2013 concerning Community Organizations has not adhered to the principle of contrarius actus so that it is not effective to implement sanctions against community organizations that adhere to, develop, and spread streams or understandings that are in conflict with the Pancasila and the 1945 Constitution of the Republic of Indonesia. Both aspects lead to the application of effective sanctions which is very relevant to the process of continued oversight of social organizations. An interesting thing to note is the emergence of the term contrarius actus principle which is considered not to exist in the previous law so that it explicitly states that the Perppu Ormas contains contrarius actus principle in its application.

The understanding of the principle, according to Philipus M. Hadjon and Tatiek Sri Djatmiati, in the Legal Arguments book states that the contrarius actus principle in state administrative law is the principle that states state administrative bodies or officials who issue state administrative decisions by themselves are also authorized to cancel them. The existence of this principle as mentioned in the preamble of the Perppu Ormas is located in the process of applying sanctions where the process is part of the follow-up process of monitoring actions by government officials. Therefore, its role in supervision should be studied in more depth in connection with the growth and development of social organizations at this time.

\section{The research method}

The research method used in this study is the normative juridical method. This normative juridical research method is carried out through library research which focuses on library data in the form of primary legal material namely legislation which in this study is Government Regulation in Lieu of Law Number 2 of 2017 concerning Amendment to Law Number 17 of 2013 concerning Social Organization and related legislation, secondary legal materials in the form of literature that has relevance to the research topic. 


\section{Research Result and Discussion}

Social Organization as regulated in Law No. 17 of 2013 states that there are two forms of Community Organizations that are legal entities and not legal entities, the establishment of both cannot be done just like that because in the process required permission from the government as the state organizer. As stated in Article 15 Paragraph (1) of Law No. 17 of 2013 concerning Community Organizations that, legal entities are declared registered after getting legalized by a legal entity. Meanwhile, CSOs that are not incorporated are regulated through Minister of Home Affairs Regulation No. 57 of 2017 which states that, Community Organizations are not incorporated legal entities are registered after obtaining a Registered Certificate (SKT), the SKT is a document issued by the Minister stating that Community Organizations are not legally registered in the state administration. The registration process for both (legal organizations and non-legal organizations) is completely set out in the implementing regulations as follows:

1. Regulation of the Minister of Home Affairs of the Republic of Indonesia Number 57 Year 2017 Concerning Registration and Management of Community Organization Information Systems

2. Regulation of the Minister of Law and Human Rights of the Republic of Indonesia Number 3 of 2016 concerning Procedures for Filing Requests for Legalization of Legal Entities and Approval of Amendments to the Association's Articles of Association

3. Regulation of the Minister of Law and Human Rights of the Republic of Indonesia Number 2 of 2016 concerning Procedures for Filing Requests for Legal Entity Approval and Approval of Amendments to the Articles of Association and Submitting Notification of Amendments to Articles of Association and Amendments to Foundation Data

The regulation regarding the procedure for registration of a social organization results in the endorsement that a Community Organization has been registered. The endorsement is a form of permit in which it is in the form of a State Administration Decree. Based on Article 1 number 3 of the State Administrative Court Law states that a State Administrative Decree is a written stipulation issued by a state administration body or official containing legal actions on state administration based on applicable legislation, which are concrete, individual and final, which have legal consequences for a person or legal entity. Indroharto explained in detail the term "written determination" referred to by the State Administrative Court Law because the written stipulation referred to contained several elements, namely the form of the stipulation must be written; it is issued by a state administration agency or official; contains legal actions in state administration; based on the applicable laws and regulations; are concrete, individual, and final; and cause legal consequences for a person or private legal entity (Indroharto, 2000; 163).

Legally the permit is an administrative authority possessed by the government as a means to oversee the activities of the community. Therefore the purpose of granting permission for the establishment of CSOs is that the government can oversee all forms of activities or in other words the licensing instrument in this case aims to direct or control the activities of CSOs to prevent the dangers that can arise as a result of these activities, in summary, the organization of social organizations. It can be seen in picture 2 . 


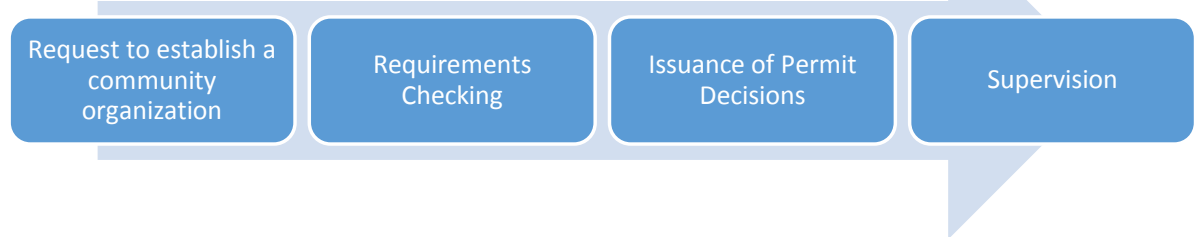

This plot has the same concept as stated by George R. Terry, in his book Principles of Management. According to him good management must meet the stages of Planning (Planning), Organizing (Organizing), Actuating (Implementation) and Controlling (Supervision) (Sukarna, Fundamentals of Management, CV Mandar Maju, Bandung, 2011, p. 10).

Picture 3: Theory of Management Stages according to George R. Terry

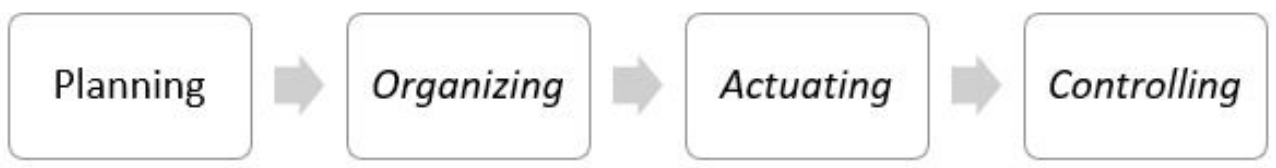

Referring to the explanation, it can be seen that the granting of permits for a Social Organization is aimed at making the government able to conduct supervision which makes the existence of supervision aspects so important in the regulation of CSOs. Supervision as stipulated in Law No. 17 of 2013 concerning Community Organizations is divided into two, namely internal and external supervision, where internal supervision is carried out in accordance with organizational mechanisms that are regulated in the Statutes / By-Laws of the relevant CSOs and external supervision is carried out by the community, government, and local governments. Supervision as referred to in Article 1 number 4 Regulation of the Minister of Home Affairs of the Republic of Indonesia Number 56 Year 2017 Concerning Supervision of Community Organizations in the Ministry of the Interior and Regional Government, Supervision is one of the management functions to ensure that the performance of CSOs runs in accordance with the goals and functions of CSOs in accordance with statutory regulations. As the mandate contained in Law No. 17 of 2013 that it is necessary to issue a Government Regulation which regulates the implementation of oversight of CSOs so that a Minister of Home Affairs Regulation of the Republic of Indonesia Number 56 of 2017 Concerning Supervision of Community Organizations within the Ministry of Home Affairs and Regional Governments with the objectives stated in Article 2, namely:

1. Ensuring that CSO activities are carried out effectively and efficiently in accordance with work plans and programs as well as statutory provisions;;

2. Improving the performance and accountability of CSOs; and

3. Ensure the implementation of the functions and objectives of Community Organizations or Community Organizations established by foreign citizens.

These objectives are carried out through a supervisory process as stipulated in the regulation and then to be followed up with related ministers related to the findings made 
by the parties overseeing the Community Organizations. As already stated, there are two types of CSO supervision, namely internal and external supervision. Internal control means the supervision carried out by the apparatuses or monitoring units established within the organization itself. These officers / supervisory units act on behalf of the leadership of the organization. This supervisory unit / unit is tasked with gathering all data and information needed by the organization. Data on progress and setbacks in the execution of work. The results of this supervision can also be used in the value of the leadership's policy (Maringan Masry Simbolon, 2004: 61). Meanwhile, external supervision means the supervision carried out by the apparatus / oversight unit from outside the organization. Next, the author attaches an external monitoring flowchart carried out by the community, ministers, governors and regents/mayors.

Picture 4: Chronology of External Oversight of Community Organizations according to Regulation of the Minister of Home Affairs of the Republic of Indonesia Number 56 Year 2017 Regarding Supervision of Community Organizations in the Ministry of the Interior and Regional Government

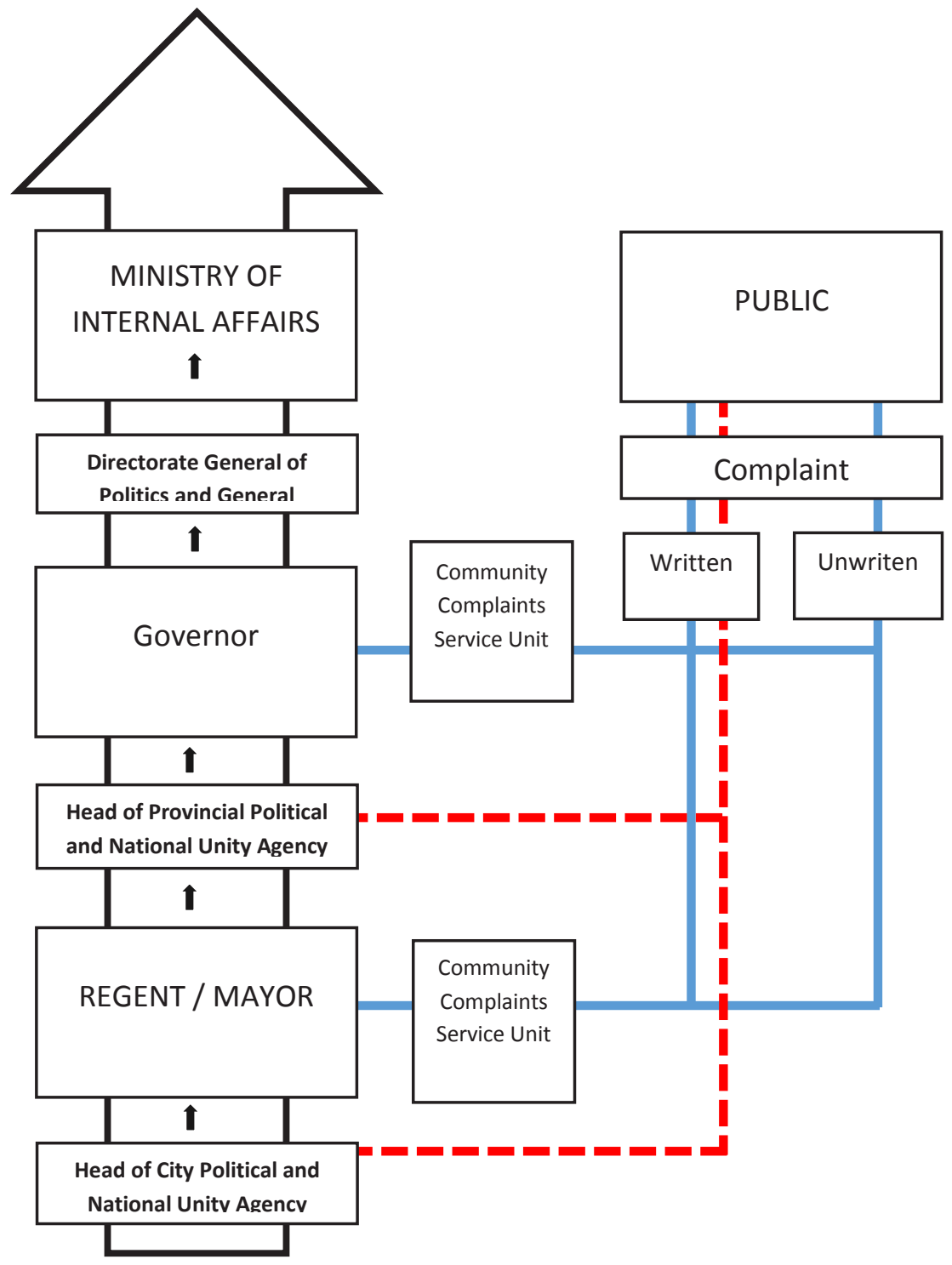


The results of the monitoring of CSOs will be followed up as a form of control of CSOs in accordance with statutory regulations. If there is an error found in the results, further action must be taken to address this matter, then government officials have the authority to apply sanctions if violations are found during monitoring a mass organization that must be done carefully by the relevant government official. If supervision can be said as a preventive measure so that CSOs remain in accordance with applicable regulations, the presence of sanctions in this case will be very important because it can force community behavior to be in accordance with the law so sanctions become inseparable from the supervision process given that supervision is controlling deviations, sanctions are legal as long as they do not conflict with the laws and regulations. In connection with this, after the issuance of the Perppu on CSOs, there was a change in the rules regarding sanctions imposed on Community Organizations that were indicated to violate those listed in Article 60 of the Perppu of CSOs stating that:

1. Community Organizations that violate the provisions referred to in Article 21, Article 51, and Article 59 paragraph (1) and paragraph (2) are subjected to administrative sanctions;

2. Community Organizations that violate the provisions referred to in Article 52 and article 59 paragraph (3) and paragraph (4) are subjected to administrative sanctions and/or criminal sanctions.

There are two type of sanctions intended in the CivilSociety Organization Regulation, which are administrative sanctions and criminal sanctions. Administrative sanctions are sanctions imposed on administrative violations or administrative provisions (https:// www.hukumonline.com/klinik/detail/ulasan/lt4be012381c490/sanksi-hukumpidana-perdata-dan-administratif-/, accessed on 07-02-2019, 02:43) while criminal sanctions are Criminal Sanctions are a cause and effect punishment, because it is the case and the consequences are the law, the affected person will get sanctions either going to prison or other sentences from the authorities (Tri Andrisman, 2009: 8). Administrative sanctions referred to in Perppu Ormas are contained in Article 61 paragraph (3) are:

1. Revocation of certificate of registration registered by the minister; or

2. Revocation of legal entity status by the minister who carries out government affairs in the legal field

Both sanctions are equally talk about revocation of a permit that has been given to the applicant, namely Ormas through a ministerial decree where the letter is categorized as a State Administration Decree (KTUN). So what is meant by administrative sanctions in the regulation is the revocation of a KTUN. Revocation of a KTUN cannot be done just like that in connection with Article 64 of Law No. 30 of 2014 concerning Government Administration which says that:

1. The decision can only be revoked if there is a defective authority; procedure; and / or substance.

2. In the event that a decision is revoked, a new decree must be issued which outlines the legal basis for revocation and considers the General Principles of Good Governance.

3. Revocation decisions can be made by government officials who make decisions; the superior of the official who sets the decision; or by court order. 
Considering that the understanding of the contrarius actus principle derived from Latin has the meaning, actions taken by a state administration agency or official that issues a state administration decision by itself (automatically) the relevant administrative body / official has the authority to revoke it. The principle of contrarius actus or can also be called as consensus contrarius (contrary action, conflicting law) is a juridical term, which refers to the previous action (actus primus) which is canceled or abolished. The contrarius actus principle has the same legal power as the actus primus. For example, laws can be changed or revoked by other legal actions, administrative actions can only be canceled by other administrative actions, and legal transactions can only be changed by other legal transactions, for example contract agreements can be revoked through revocation contracts (M Lutfi Chakim, 2017 : 78). That, what is meant by administrative sanctions in the Civil Society Organization Regulation has elements that are in accordance with the understanding of the contrarius actus principle as mentioned. That is because the revocation of the registered certificate in this case the revocation is carried out by the minister who issued the registered certificate as well as the decree on the ratification of the legal entity of the CSOs that revokes the ratification of the legal entity is the Minister of legal and human rights matters which is in accordance with Regulation of the Minister of Law and Human Rights of the Republic of Indonesia Number 3 of 2016 concerning Procedures for Filing Requests for Legalization of Legal Entities and Approval of Amendments to the Association's Articles of Association. So that the elements of the contrarius actus principle in implementing administrative sanctions in the Civil Society Regulation are fulfilled because the revocation is done automatically (automatically) by the state administration official who issued the State Administration Decree.

The explanation above provides a common thread that the role of the contrarius actus principle in terms of monitoring CSOs as the application of sanctions in the form of administrative sanctions, which is reinforced by the role to respond or react to noncompliance with the provisions contained in the decision which in this case is ratification as a registered CSO and also ratification of CSOs as legal entities, in other words that the placement of sanctions in terms of monitoring CSOs is a follow-up to the results of monitoring and evaluation conducted by external supervisors of CSOs with the aim of being able to control the initial objectives of the formation of an organization that is in accordance with the objectives of the state and national development.

As explained in the previous section that the role of the principle is explained in the previous section that the role of the contrarius actus principle in overseeing Community Organizations is in the administrative sanctions section in which it is a continuation of the results of supervision carried out externally. Administrative sanctions are acts of government to end a state that is prohibited by the rules of administrative law or do what should be left by the citizens because it is contrary to the law or other legal rules (Philipus M Hadjon, 1994: 246).

Given the initial opinion that naturally human individuals are social beings who have a tendency to live in groups and organizations. The author is of the opinion that the application of administrative sanctions imposed on Community Organizations that violate will have an impact not only on Community Organizations as a form of organization but also on the human individuals within it. The influence of these principles on the Growth and Development of CSOs, according to the author, is not 
directly apparent. Given that the law is an act that functions as a means of controlling social security that is different from other rules, which are known to have 4 attributes of law as follows:

1. Attribute of authority; that the law is a decision which is intended to overcome the tensions that occur in society

2. Attribute of intention of universal application; that the decisions of the authorities have a long reach for the future

3. Attribute of obligation; that the decisions of the authorities must contain party-to-party obligations to the second-party and vice versa

4. Attribute of sanction; that decisions from the authorities must be accompanied by sanctions that are based on real community power

It needs to be underlined that the decision of the authorities has a long reach for the future, the authors interpret in relation to the influence of the contrarius actus principle on the growth and development of CSOs that their application will affect the development of CSOs in the future as it is known that the application of sanctions is a further action from corrective supervision, which is to improve conditions that were previously deviated so that each individual community in using its right to associate will be more careful in carrying out all its activities and activities in the interest of the so that the CSOs that are being carried out can continue to develop.

\section{Conclusion}

The author raises the role of the contrarius actus principle in terms of oversight of Community Organizations as the application of sanctions in the form of administrative sanctions, which are emphasized by the role to respond or react to non-compliance with the provisions the provisions contained in the decision where in this case is ratification as a registered Community Organizations and also ratification of Community Organizations as a legal entity. In addition, given that naturally human individuals are social beings who have a tendency to live in groups and organizations. The author believes that the application of administrative sanctions applied to violating CSOs will have an impact not only on CSOs as a form of organization but also on the human individuals within them so that the influence of these principles on the Growth and Development of Community Organizations according to the authors is not directly apparent. The author's suggestion is to remember that what is the object of the application of the contrarius actus principle is a State Administration Decree, so in its implementation it needs to be done carefully considering Benny M. Junus's preformance in his book entitled Institutional Law of State Administration said that, Decisions of government officials which is juridical in nature, and contains stipulations (beschikking) is one of the types of activities which greatly affects the life of the state and society, which has legal consequences and will be dangerous if taken in a less responsible manner.

\section{BIBLIOGRAPHY}

\section{Books:}

Jimly Asshiddiqie. (2006). Kemerdekaan Berserikat, Pembubaran Partai Politik dan Mahkamah Konstiusi. Jakarta: Konstitusi Press. 
Indroharto. (2000). Usaha Memahami Undang-Undang Peradilan Tata Usaha Negara. Jakarta: Pustaka Sinar Harapan.

Maringan Masry Simbolon. (2004). Dasar - Dasar Administrasi dan Manajemen. Jakarta : Ghalia Indonesia.

Philipus M Hadjon. (1994). Pengantar Hukum Administrasi Indonesia. Yogyakarta: Gadjah Mada University Press.

Sukarna. (1994). Dasar-Dasar Manajemen. Bandung: Mandar Maju.

Tri Andrisman. (2009). Asas-Asas dan Dasar Aturan Hukum Pidana Indonesia. Bandar Lampung : Unila.

\section{Legal Documents:}

Law Number 8 of 1985 on Community Organization

Law Number 16 of 2017 on Establishment of Government Regulation in Lieu of Law Number 2 of 2017 on Amendment of Law Number 17 of 2013 on Community Organization.

Government Regulation In Lieu of Law Number 2 of 2017 on Amendment of Law Number 17 of 2013 on Community Organization

Ministerial Regulation Number 56 of 2017 on Supervision of Community Organizations in the Ministry of the Interior and Regional Government

Minister of Law and Human Right Regulation Number 2 of 2016 on Procedure for Submitting Request for Legalization of Legal Entity and Approval of Amendment to the Articles of Association and Submission of Notification of Amendment to Articles of Association and Amendment of Foundation Data.

Minister of Law and Human Rught Regulation Number 3 of 2016 on Procedure for Submitting Request for Legalization of Legal Entity and Approval for Amendment to Articles of Association

Decree's People Consultative Assembly of The Republic of Indonesia Number : II/ Mpr/1983 on Outlines of State Policy

\section{Journals:}

M Lutfi Chakim. (2017). "Contrarius Actus" Majalah Konstutusi. No. 126, Agustus 2017.

\section{Websites:}

https:// www.hukumonline.com/klinik/detail/ulasan/lt4be012381c490/sanksihukum-pidana-perdata-dan-administratif-/, Sanksi Hukum (Pidana, Perdata, dan Administratif), accessed on 2 July 2019 